\title{
FDI Location Choices under Uncertainty: A Binomial Options-Based Approach
}

\author{
F. Calò ${ }^{1, *}$, F. Pizzutilo ${ }^{2, *}$ \\ ${ }^{1}$ University of Urbino “Carlo Bo”, Ph.D. candidate in Economics, Society, Law \\ ${ }^{2}$ Department of Business and law studies, University of Bari “Aldo Moro”, Bari, Italy \\ *Corresponding author: francesco.calo@uniurb.it; fabio.pizzutilo@uniba.it
}

Received March 02, 2014; Revised March 11, 2014; Accepted March 16, 2014

\begin{abstract}
The competitive advantages of foreign direct investment can be largely dependent on location. In this study, we develop an innovative model to deal with this crucial step for any multinational involved in expanding its operations abroad. The model has a pure financial perspective and is based on a binomial approach. An application of the model explores its practical implementation and outlines the extent to which different financial variables impact on the location choice of foreign direct investment.
\end{abstract}

Keywords: location choice, foreign direct investment, FDI, multinational companies, MNC, multinational enterprises, MNE, entry mode choice

Cite This Article: F. Calò, and F. Pizzutilo, "FDI Location Choices under Uncertainty: A Binomial OptionsBased Approach.” Journal of Finance and Economics, vol. 2, no. 3 (2014): 70-74. doi: 10.12691/jfe-2-3-3.

\section{Introduction}

The reasons for a firm to directly invest abroad are numerous and heterogeneous. A company can decide upon foreign direct investment (FDI) to imitate competitors; to cope with foreign market needs; to chase opportunities in foreign markets; to consolidate its position in the home market; to achieve economies of scope or scale; to benefit from cheaper raw materials; to utilize low-skilled or lowcost workers; and so on. Following Dunning (1993, 2000), the motivations behind FDI can be classified into four groups: market-seeking, efficiency-seeking, resourceseeking and strategic asset-seeking.

Different FDI orientations can result indifferent solutions depending on the country (and/or the region of the foreign country) where investment is made. The countries that are preferred by one firm may not be the favourite of other companies. In this context, Makino, Lau and Yeh (2002) concluded that firms who aim to exploit their asset advantages prefer to invest in less developed countries, while firms with a strong asset-seeking orientation tend to concentrate their FDIs in developed countries. Prior to deciding how to enter a market, a multinational enterprise (MNE) has to decide where to invest. This choice should be coherent with the goals that the MNE is looking to exploit from the FDI. Moreover, the location must be one that maximizes the expected value of the advantage that the MNE is trying to capitalize on through direct investment abroad.

The location choice of an FDI is thus a crucial step for any MNE expanding its operations abroad, with the competitive advantages of a FDI largely dependent on its location.
However, uncertainty plays an important role in all strategic decision, since it affects the variability of the results of any business, thus implying risks as well as opportunities. The more uncertainty there is, the more unfavourable the conditions that could potentially hit the business- although conversely, it also means the more opportunities that could arise. The location of a new FDI is not immune to this rule. As such, there is a need to analyse MNEs' location choices under uncertainty. Real options theory offers a conceptual framework through which to incorporate uncertainty into FDI theory.

Rather than concentrate on an analysis of the factors that can drive location choice -as most of the existent literature on the subject does -we propose in these pages an alternative tool to cope with the choice, which is based on a binomial view of the problem. The model has a purely financial perspective and considers the (modified) net present value that is realizable by the FDI as the unique variable driving location choice.

This study extends the extant literature on FDI and MNEs by offering a number of contributions. First, it develops an integrated theoretical and practical framework that combines the L part of Dunning's (1980) eclectic paradigm (where certain motivations push firms to directly invest abroad) to the financial principles of investment decisions. Second, it stresses the importance of a non-negligible factor that should be taken into account when firms decide where to locate an FDI, namely the variability of net cash flows. Third, it extends the application of real options theory to the research area of FDI location choices.

The paper is outlined as follows. Section 2 reviews the relevant literature. Section 3 specifies the model. An application of the model is shown in Section 4 and Section 5 concludes. 


\section{Literature Review}

The location choices of FDIs have been the focal point of a large number of papers in international business studies ever since the nineties.

Kumar (1996) concentrated his research on the determinants of location for overseas research and development (R\&D) activity by US multinationals, and found that MNEs prefer to locate their R\&D activities in countries that offer larger markets, technological resources and infrastructure.

Yamouri (1998) investigated the factors that affected the location choice of Japanese multinational financial institutions. He found that the manufacturing industry's FDI location choices were an important determinant. In contrast to studies of the US, he also found that local banking opportunities in the host country play a nonnegligible role.

Chung and Alcacer (2002) examined whether and when a country's technical capabilities attract foreign investments. They found that, on average, state R\&D intensity does not attract FDI in the manufacturing industry and that firms in research-intensive industries are more likely to locate in states with high R\&D intensity. Interestingly, they provide evidence that firms from technically leading nations are attracted to R\&D-intensive states.

Bevan, Estrid and Meyer (2004) examined the relationship between institutional development and FDI inflow, and found that FDIs are positively related to the quality of formal institutions. In particular, they conclude that private ownership of business, banking sector reform, foreign exchange, trade liberalization and legal development are key factors in attracting FDIs. Conversely, domestic price liberalization, non-bank financial sector development and competition policy do not enhance FDIs.

Nachumb and Wymbs (2005), found significant association between product differentiation and the preferences of firms for proximity to other firms in their industry. Even after having controlled for other firmspecific attributes, their findings show that product differentiation exerts a strong and significant influence on the location decisions of MNEs.

Lei and Chen, (2011) investigated the location choice of firms originating from newly industrialized economies. Among other things, they found that firms with stronger ownership advantages and those with strong resourceseeking motives prefer to invest in more developed regions over less developed countries.

Kang and Jiang (2012) suggested that while traditional economic factors have a major role to play in affecting Chinese MNEs' decisions on FDI location, institutional variables play a more dynamic and significant role. They also concluded that location choices by Chinese MNEs tended to have different patterns, both for different regional economy groups and across different time periods.

Azemar, Darby, Desbordes and Wooton (2012) explored how MNEs' location decisions are shaped by better acquaintance with foreign markets, which are a consequence of bilateral ties, experience of international expansion and knowledge of how to deal with poor governance. They found that these aspects of market familiarity induce significant differences between northern hemisphere and southern hemisphere MNEs in terms of location behaviour in developing countries.

At the same time, real options theory has been introduced in the area of FDI studies with very notable contributions, highlighting the need for a more dynamic and flexible perspective.

Dixit (1989) was one of the first scholars to approach foreign trade decisions under uncertainty using options theory. Meanwhile, Kogut and Kulatilaka (1994) were the firsts to model MNEs' international production flexibility as an option largely dependent upon exchange rates.

Chi and McGuire (1996) investigated how transaction costs and strategic options influence a firm's evaluation of international collaborative venturing (ICV). They concluded that the initial stage of ICV can be viewed as a vehicle for learning more about the partner for future expansion, and thus reduces the existence of certain ex ante asymmetries between partners. They also explicated the conditions that determine whether the option to acquire or sell out provides an economic value for ICV partners.

Panayi and Trigeorgis (1998) successfully modelled a bank's international expansion through a multi-stage compounded real options model. This involved a staged capital commitment conditioned to market favourable conditions.

Botteron, Chesney and Gibson-Asner (2006) used an approach based on barrier options to model production and sales delocalization decisions for MNEs under exchange rate uncertainty. Among other things, their riskneutral options pricing framework showed how macroeconomic variables influence a firm's delocalization decisions.

Gilroy and Lukas (2006) proposed a two-phase real options approach with which to model foreign market entry choices under uncertainty. This model differentiates between the two most important equity-based entry modes: greenfield investment and cross-border M\&A. The results suggest that uncertainty and future investment opportunities play an important role in terms of transit from export to the first phase of FDI commitment, while as also having an impact on the choice of entry strategy.

Li and Rugman (2007) employed two real optionsbased models to examine: 1) the conditions under which an MNE prefers a location in its home region to a location in a non-home region for market-seeking FDI; and 2) the conditions under which each market entry mode (export/licensing, joint venture, or a wholly owned subsidiary) is preferred.

Tong and Reuer (2007) investigated the effects of multinationality on firms' risk levels. They identified international operations as switching options that create values for MNEs. In their model, the coordination costs of such flexibility mitigated the benefits of the switching opportunities.

Lukas (2007) formalized the optimal choice of an MNE's market entry strategy from a dynamic perspective by taking a three-step expansion strategy into account. He proposed an interesting real options model in a continuous time setting, which makes use of two kinds of financial options: compound options and complex chooser options.

Driouchi and Bennett (2011) suggested that real options learning can be a source of competitive advantage for multinational corporations. They also found that MNEs 
which have high managerial awareness of their real options are able to reduce their downside risk through multinationality, organisational slack and other firm characteristics.

Aray and Gardeazabal (2010) considered how an exporting firm which competes in an oligopolistic market faces exchange rate uncertainty. They proposed a model to evaluate the convenience of setting up a plant abroad, where real options are employed in order to determine the right timing of the investment.

Kallio, Kuula and Oinonen (2011) developed a model for the evaluation of the FDIs which makes use of real options, and which also admits imperfect and incomplete markets under certain conditions.

Using a real options perspective, Dikova, Smeets Garretsen and Van Ees (2013) examined short-term responses to financial crises at US multinational firm subsidiaries. Their analysis suggested that relocating a subsidiary's output is an effective short-term response to local financial crises, and that financial crises cause increases in the value of 'across-country' options relative to 'within-country' ones.

In this paper, we further extend these streams of research.

\section{Methodological Assumptions and Model Construction}

In an OLI framework, (Dunnings, 1980) a firm that is motivated to exploit location-specific advantages provided by the host country is considered through internalizing its specific advantages. This supposes that many countries maybe suitable; however, for the sake of simplicity, we assume that the choice can be restricted to countries A, B and $\mathrm{C}$. Moreover, we assume that investments will start at time 0 and that the plants will be fully operative at time 1, when production will be ready to be delivered. Regardless of the foreign country, the plant will be realized so that it will be able to produce the same product in identical quantities. The investment (I) needed to realize the new plant can obviously be different from country to country. The production will be distributed in the same final market so that uncertainty surrounding the market price of the finished product and its demand is the same whatever the location choice. In this respect, $\mathrm{Pt}$ is the cash flow that the MNE expects to achieve at time $t$ from selling the new FDI's product.

In light of the options theory, we can propose the investment (I) to be the premium that the MNE pays in order to achieve the (real) call option. This will gain the net cash flows generated from the new plants from time 1 until the end of the production.

The cost of the finished product on the final market and the value of the initial investment (I) are therefore the variables that mainly influence FDI location choice. Labour costs, taxation, raw material transportation costs, finished product transportation costs, energy costs, strikes, administrative expenses, duties, exchange rates, inflation and upkeep expenses are the main factors that can influence the final production cost in each country(A, B or C). However, the extent to which these factors affect the final production cost can be assumed to be different from country to country.
$\mathrm{C}_{\mathrm{At}}, \mathrm{C}_{\mathrm{Bt}}$ and $\mathrm{C}_{\mathrm{Ct}}$ represent the final production cost in country $\mathrm{A}, \mathrm{B}$ and $\mathrm{C}$, respectively. We can assume that the production cost uncertainty is of a binomial nature; that is, at each point from 1 to $t$ it can be either high (h) or low (l). Consequently, $\mathrm{C}_{\mathrm{A} 1 \mathrm{~h}}$ indicates the final production cost in country $\mathrm{A}$ at time 1 when assuming a high level of costs; $\mathrm{C}_{\mathrm{A} 1 \mathrm{l}}$ is the final production cost in country $\mathrm{A}$ at time 1 when assuming a low level of costs; $\mathrm{C}_{\mathrm{B} 1 \mathrm{~h}}$ indicates the final production cost in country $B$ at time 1 when assuming a high level of costs; and so on with $\mathrm{C}_{\mathrm{A} 1 \mathrm{~h}} \neq \mathrm{C}_{\mathrm{B} 1 \mathrm{~h}} \neq \mathrm{C}_{\mathrm{C} 1 \mathrm{~h}}$ and $\mathrm{C}_{\mathrm{A} 1 \mathrm{l}} \neq \mathrm{C}_{\mathrm{B} 1 \mathrm{l}} \neq \mathrm{C}_{\mathrm{C} 11}$. Thus, according to the location of the FDI and the level of production costs, the final expected net cash flow at time 1 will be:

$$
\max \left[\left(\mathrm{P}_{1}-\mathrm{C}_{\mathrm{a} 1 \mathrm{~h}}\right) ; 0\right] \text { or } \max \left[\left(\mathrm{P}_{1}-\mathrm{C}_{\mathrm{a} 1 \mathrm{l}}\right) ; 0\right] \text {; }
$$

where $\alpha$ denotes the country where the FDI is located. Obviously, the MNE will refrain from producing if expected production costs will be higher than expected revenues.

The FDI will be located where the expected final net cash flow $(\mathrm{P}-\mathrm{C})$ is maximized when initial investment is taken into account.

$\mathrm{V}$ signifies the net cash flow difference (P-C). According to Harrison and Kreeps (1979), we can assume that there are no arbitrage opportunities to be exploited in the financial markets. Moreover, assume that financial markets are completein the meaning of Duffie and Huang (1985). This leads us to approach the problem in the binomial view of Cox, Ross and Rubinstein (1979).

According to the option pricing theory, the risk neutral valuation method relies on the assumption that it is not possible to conclude arbitrages in the market; as such, uncertainty is already reflected in the future values of the underlying assets. This allows us to calculate the theoretical probabilities under market risk neutrality conditions (i.e. in the presence of an expected return equal to the risk-free rate, Hull 2012). In this case, the expected cash flow at time $t$ is the average cash flow weighted by the theoretical probabilities under these conditions. The price of the option is the present value at the risk-free rate of this expected cash flow. In our framework:

$$
\begin{aligned}
& V_{A 0}=\frac{w_{A 1} V_{A 1 l}+\left(1-w_{A 1}\right) V_{A 1 h}}{e^{r f}} \\
& V_{B 0}=\frac{w_{B 1} V_{B 1 l}+\left(1-w_{B 1}\right) V_{B 1 h}}{e^{r f}} \\
& V_{C 0}=\frac{w_{C 1} V_{C 1 l}+\left(1-w_{C 1}\right) V_{C 1 h}}{e^{r f}}
\end{aligned}
$$

where $r_{f}$ is the risk-free rate and $w$ is the risk-neutral probability that the value of the underlying increases at time 1 (note that the value of the underlying increases if the production costs decreases):

$$
\begin{gathered}
\text { free_risk_rate } \\
w=\frac{\text {-variation_in_reduction }}{\text { variation_in_increase }} \\
\text { - variation_in_reduction }
\end{gathered}
$$

$\begin{aligned} \text { variation_in_increase } & =e^{\sigma \sqrt{t}}-1 \\ \text { where: } & \text { variation_in_reduction }=\frac{1}{e^{\sigma \sqrt{t}}}-1\end{aligned}$ 
With $\sigma$ being the standard deviation of the returns of the underlying.

We then determine $I_{A}, I_{B}$ and $I_{C}$ to be the values of the investment in countries $\mathrm{A}, \mathrm{B}$ and $\mathrm{C}$, respectively. If the investments alternate with each other, country A will be preferred if:

$$
\begin{aligned}
& \left(\mathrm{V}_{\mathrm{A} 0}-\mathrm{I}_{\mathrm{A}}\right)>\left(\mathrm{V}_{\mathrm{B} 0}-\mathrm{I}_{\mathrm{B}}\right) \\
& \text { and }\left(\mathrm{V}_{\mathrm{A} 0}-\mathrm{I}_{\mathrm{A}}\right)>\left(\mathrm{V}_{\mathrm{C} 0}-\mathrm{I}_{\mathrm{C}}\right) \\
& \text { verified that }\left(\mathrm{V}_{\mathrm{A} 0}-\mathrm{I}_{\mathrm{A}}\right)>0
\end{aligned}
$$

The FDI will be localized in country B if:

$$
\begin{aligned}
& \left(\mathrm{V}_{\mathrm{B} 0}-\mathrm{I}_{\mathrm{B}}\right)>\left(\mathrm{V}_{\mathrm{A} 0}-\mathrm{I}_{\mathrm{A}}\right) \\
& \text { and }\left(\mathrm{V}_{\mathrm{B} 0}-\mathrm{I}_{\mathrm{B}}\right)>\left(\mathrm{V}_{\mathrm{C} 0}-\mathrm{I}_{\mathrm{C}}\right) \\
& \text { verified that }\left(\mathrm{V}_{\mathrm{B} 0}-\mathrm{I}_{\mathrm{B}}\right)>0
\end{aligned}
$$

and in country $\mathrm{C}$ if:

$$
\begin{aligned}
& \left(\mathrm{V}_{\mathrm{C} 0}-\mathrm{I}_{\mathrm{C}}\right)>\left(\mathrm{V}_{\mathrm{A} 0}-\mathrm{I}_{\mathrm{A}}\right) \\
& \text { and }\left(\mathrm{V}_{\mathrm{C} 0}-\mathrm{I}_{\mathrm{C}}\right)>\left(\mathrm{V}_{\mathrm{A} 0}-\mathrm{I}_{\mathrm{A}}\right) \\
& \text { verified that }\left(\mathrm{V}_{\mathrm{C} 0}-\mathrm{I}_{\mathrm{C}}\right)>0
\end{aligned}
$$

A binomial tree allows us to extend the model in order to consider n periods, where:

$$
\begin{aligned}
V_{A t} & =\frac{w_{A(t+1)} V_{A(t+1) l}+\left(1-w_{A(t+1)}\right) V_{A(t+1) h}}{e^{r f}} \\
V_{B t} & =\frac{w_{B(t+1)} V_{B(t+1) l}+\left(1-w_{B(t+1)}\right) V_{B(t+1) h}}{e^{r f}} \\
V_{C t} & =\frac{w_{C(t+1)} V_{C(t+1) l}+\left(1-w_{C(t+1)}\right) V_{C(t+1) h}}{e^{r f}}
\end{aligned}
$$

Note that $\mathrm{V}$ can either be observed as $\left(\mathrm{P}_{2}-\mathrm{C}_{2}\right)$, enabling to model not only the variability in production costs, but also the selling price of the final product too.

It is evident that the model is easily extendible to $n$ countries.

\section{Application}

We conducted a set of simulations based on the model described in section 3 with the aim of finding out how the location choice is influenced by: a) different investment values; b) different production costs; c) different levels of uncertainty; and d) different risk-free rates.

We assumed that the MNE is comparing a new investment in its home country $(\mathrm{H})$ to an FDI in a country located on the same continent $(\mathrm{C})$ and in a country in another part of the world (F). This can be seen as a synthesis of a typical dilemma faced by European or US firms which intend to expand their production. A European firm can invest in-house or in nearby (psychically and geographically) Eastern Europe or further away (psychically and geographically) in South-east Asian subcontinent. The US firm can delocalize into nearby Mexico or Latin America or choose to invest further away in Asia.

Assume that the investment for the new plant in the home country is 100 , it is 90 in $\mathrm{C}$ and 80 in $\mathrm{F}$ and that production costs are expected to be 10 in $\mathrm{H}, 9$ in $\mathrm{C}$ and 8 in F. The final price of the production on the selling market is expected to be 25 . We assume that volatility in the final net cash flow induced by the volatility of production costs is $4 \%, 8 \%$ and $12 \%$ in $\mathrm{H}, \mathrm{C}$ and $\mathrm{F}$, respectively. The new plant is expected to produce for 10 years, at the end of which it must be dismantled with no terminal value (in other words, the costs of the dismantling offset the income from the liquidation of the remaining assets). All values are expressed in $\mathrm{H}$ currency and are real (i.e. depurated from expected inflation); therefore the risk-free rate is the real $\mathrm{H}$ currency one, assume $2 \%$.

Using these assumptions, the model described in the previous section indicates that the optimal choice is to locate the investment in the most distant region. The investment appears to destroy value if located at home, but creates a low positive value if located in a continental country. Following the details of the results:

$$
\begin{aligned}
& \mathrm{V}_{\mathrm{H}}=127.84, \mathrm{~V}_{\mathrm{C}}=138.18, \mathrm{~V}_{\mathrm{F}}=148.87 \\
& \mathrm{~V}_{\mathrm{H}}-\mathrm{I}_{\mathrm{H}}=+27.84, \mathrm{~V}_{\mathrm{C}}-\mathrm{I}_{\mathrm{C}}=+48.18, \mathrm{~V}_{\mathrm{F}}-\mathrm{I}_{\mathrm{F}}=+68.87
\end{aligned}
$$

It becomes evident that the location choice is strictly related to the value of the investment (I). All other things being equal, choice $\mathrm{C}$ becomes preferable if the initial investment is lower than 69.31, whilst the new plant should be located at home if, all other things being equal, the investment is lover than 58.97.

Our model also makes it immediately apparent that an increase in production costs reduces the attractiveness of the location. All other things being equal, country $\mathrm{C}$ will be preferred if production costs in country $\mathrm{F}$ are higher than 10.07 (note that the investment in country $\mathrm{F}$ is assumed to be more than $11 \%$ lower), whereas the homeland location is preferred when production costs in country $\mathrm{F}$ are higher than 10.07 and production costs at home are lower than 7.94.

The variability of the net income from the selling the final product increases the risk of FDI. However, if production costs are higher than the selling price, the MNE can temporarily suspend production. A traditional net present value analysis catches the first variable only. Given (1), the options-based approach proposed here also appreciates the abandonment option (Robicheck, Van Horne, 1967). The net effect on the value of the FDI can be negative or positive according to the reduction in value implied by the risk increase, which should overcome the value of the real abandonment option. Under the basic assumptions of our application, a volatility increase of $2 \%$ in each of the three hypotheses will lead to a value increase of $0.42,0.73$ and 1.03 for projects $\mathrm{H}, \mathrm{C}$ and $\mathrm{F}$, respectively.

The net present value of the FDI's periodical outcomes tends to diminish if the risk-free rate increases; as such, the value of the investment is to be considered inversely related to the risk-free rate of interest. All other things being equal, the modified present values of the investments compared in this application are122.45, 131.92 and 141.99 for projects $\mathrm{H}, \mathrm{C}$ and F, respectively, if a risk-free rate of $3 \%$ is assumed; if $r_{f}$ is posed at $4 \%$, then the values are $119.42,126.61$ and 136.49 , respectively

Given (1) the MNE has the possibility of do not product when costs are expected to be higher than the final selling price. Thus, the value of the FDI is positively related to its length. Assuming an expiration of 5 years, the value of $\mathrm{H}$ 
is 57.94, the value of $\mathrm{C}$ is 68.18 and the value of $\mathrm{F}$ is 73.98. If the project is assumed to be fully operational for 15 years, its value is $141.20,152.70$ and 164.43 in country $\mathrm{H}, \mathrm{C}$ and $\mathrm{F}$, respectively.

\section{Conclusions}

The competitive advantages of FDI are largely dependent on location. Hence, MNEs have to be careful when evaluating which market is best to enter when looking to maximize the expected value of the advantages it is trying to capitalize on. Moreover, uncertainty further complicates this crucial decision.

Complementarities among the classical valuation methods based on net present value and the option theory have prompted a stream of particularly rich and stimulating financial research studies, which have provided management with powerful instruments with which to analyse investment decisions.

In this context, we analysed FDI location choices under uncertainty using a binomial approach. The model developed here is from a purely financial perspective and considers the (modified) net present value realizable by the FDI as the unique variable that drives location choice.

Using an OLI framework, we considered a firm that is motivated to exploit location-specific advantages. In light of options theory, we determined investment to be the premium that a MNE pays in order to achieve the (real) call option to gain net cash flows generated from the new plants. We thus approached the problem in the binomial risk-neutral framework of Cox, Ross and Rubinstein (1979).

The model proposed is easily extendable to $\mathrm{n}$ periods and to $\mathrm{n}$ countries, and is easily adaptable so that different variables affecting the profitability of a specific business can be taken into account.

We then conducted a set of simulations with the aim of finding out how location choice is influenced by: a) different investment values; b) different production costs; c) different levels of uncertainty; and d) different risk-free rates. We found that: 1) all these variables can have a significant effect on the decision-making process; and 2) changes in their values, though low, can modify the optimal location choice for the FDI.

\section{References}

[1] Aray, H., Gardeazabal, J., (2010). Going multinational under exchange rate uncertainty, Journal of International Money and Finance, 29, pp. 1171-1191.

[2] Azemar, C., Darby, J., Desbordes, R., Wooton, I., (2012). Market Familiarity and the location of south and north MNEs, Economics \& Politics, 24, pp. 307-354.

[3] Bevan, A., Estrid, S., Meyer, K., (2004). Foreign investment location and institutional development in transition economies, International Business Review, 13, pp. 43-64.

[4] Botteron, P., Chesney, M., e Gibson-Asner, R., (2003). Analyzing firms' strategic investment decisions in a real options' framework, International Financial Markets, Institution and Money, 13, pp. 451-479.

[5] Chi, T., McGuire, D. J., (1996). Collaborative Ventures and Value of Learning: Integrating the Transaction Cost and Strategic Option Perspectives on the Choice of Market Entry, Journal of International Business Studies, 27(2), pp. 285-307.
[6] Chung, W., Alcácer, J., (2002). Knowledge Seeking and Location Choice of Foreign Direct Investment in the United States, Management Science, 48(12), pp. 1534-1554.

[7] Cox, J. C., Ross, S. A., Rubinstein, M. (1979). Option pricing: A simplified approach. Journal of Financial Economics, 7(3), pp. 229-263.

[8] Dikova, D., Smeets, R., Garretsen H., Van Ees, H., (2013). Immediate responses to financial crises: A focus on US MNE subsidiaries, International Business Review, 22, pp. 202-215.

[9] Dixit, A., (1989). Entry and Exit Decisions under Uncertainty. Journal of Political Economy, 97(3), pp. 620-638.

[10] Driouchi, T., Bennet, D., (2011). Real options in multinational decision-making: Managerial awareness and risk Implications, Journal of World Business, 46, pp. 205-219.

[11] Duffie, D., \& Huang, C. (1985). Implementing Arrow-Debreu equilibria by continuous trading of few long lived securities. Econometrica, 53, 1337-1356.

[12] Dunning, J. H. (1980).Towards an Eclectic Theory of International Production: Some Empirical Tests, Journal of International Business Studies, 11(1), pp. 9-31.

[13] Dunning, J. H. (1993). Multinational enterprises and the global economy. Reading, MA: Addison Wesley.

[14] Dunning, J. H. (2000). The eclectic paradigm as an envelope for economic and business theories of MNE activity. International Business Review, 9(1), pp. 163-190.

[15] Gilroy, B. M., Lukas, E., (2006). The choice between greenfield investment and cross-border acquisition: A real option approach, The Quarterly Review of Economics and Finance 46, pp. 447-465.

[16] Harrison, J. M., Kreps, D. M., (1979). Martingales and arbitrage in multiperiod securities markets, Journal of Economic Theory, 20(3), pp. 381-408.

[17] Hull, J. C., (2011). Option, Futures and other derivatives, 7th edition, Pearson.

[18] Kallio, M., Kuula, M., Oinonen, S., (2011). Real options valuation of forest plantation investments in Brazil, European Journal of Operational Research 217, pp. 428-438.

[19] Kang, Y., Jiang, F., (2012). FDI location choice of Chinese multinationals in East and Southeast Asia: Traditional economic factors and institutional perspective, Journal of World Business, 47, pp. 45-53.

[20] Kogut B., Kulatilaka, N., (1994). Operating Flexibility, Global Manufacturing, and the Option Value of a Multinational Network, Management Science, 40(1), pp. 123-139.

[21] Kumar, N., (1996). Intellectual Property Protection, Market Orientation and Location of Overseas R\&D Activities by Multinational Enterprises, World Development, 24(4), pp. 673688.

[22] Lei, H., Chen, Y., (2011). The right tree for the right bird: Location choice decision of Taiwanese firms' FDI in China and Vietnam, International Business Review, 20, pp. 338-352.

[23] Li, J., Rugman, A.M., (2007). Real options and the theory of foreign direct investment, International Business Review, 16, pp. 687-712.

[24] Lukas, E., (2007). Dynamic market entry and the value of flexibility in transitional international joint ventures, Review of Financial Economics, 16, pp. 91-110.

[25] Makino, S., Lau, C. M., Yeh, R. S., (2002). Asset-exploitation versus asset-seeking: Implications for location choice of foreign direct investment from newly industrialized economies. Journal of International Business Studies, 33(3), 403-421.

[26] Nachum, L., Wymbs, C., (2005). Product differentiation, external economies and MNE location choices: M\&As in Global Cities, Journal of International Business Studies, 36(4), pp. 415-434.

[27] Panayi, S., Trigeorgis, L., (1998). Multi-stage Real Options: The Cases of Information Technology Infrastructure and International Bank Expansion, The Quarterly Review of Economics and Wnance, 38, Special Issue, pp. 675-692.

[28] Robicheck, A., Van Horne, J., (1967). Abandonment Value and Capitla Budgeting, Journal of Finance, 22(4), pp. 577-589.

[29] Tong, T. W., Reuer, J.J., (2007). Real Options in Multinational Corporations: Organizational Challenges and Risk Implications, Journal of International Business Studies, 38, pp. 215-230.

[30] Yamouri, N., (1998). A note on the location choice of multinational banks: The case of Japanese financial institutions, Journal of Banking \& Finance, 22, pp. 109-120. 